WIELKIE TEMATY KULTURY W LITERATURACH SKOWIAŃSKICH

Slavica Wratislaviensia CLXVIII • Wrocław 2019•AUWr No 3875

DOI: 10.19195/0137-1150.168.32

Data przesłania artykułu: 10.10 .2017

Data akceptacji artykułu: 2.01.2018

TEREZIE FOLDYNOVÁ

Ostravská univerzita v Ostravě, Republika Czeska

\title{
Mystická smrt ve vybraných prózách Jáchyma Topola
}

Charakteristickým rysem próz Jáchyma Topola je téma mystické iniciace s přesahy do alchymie, jejíž vznešenou formu autor devalvuje např́íklad častým užíváním groteskních prvků. Alchymistická iniciace je velmi úzce spjata s motivy smrti a zmrtvýchvstání, které v Topolově tvorbě sehrávají klíčovou roli. Duchovní obroda jeho hrdinů probíhá vždy současně s celospolečenskou transformací, přičemž interakce mezi světem a jeho člověkem je $v$ tomto prŕípadě vždy akcentována $\mathrm{v}$ momentě hluboké krize, jež je fatální pro obě polohy. Než přistoupíme k motivické analýze vybraných titulů Sestra (1994), Anděl (1995) a Noční práce $(2001)^{1}$, pokusíme se alespoň stručně přiblížit hlavní teze alchymie a následně představíme jednotlivé fáze alchymistické transformace ${ }^{2}$.

\section{Iniciační schéma $\mathrm{v}$ kontextu alchymie}

Alchymie je křest’anskou herezí, jejíž myšlenková koncepce nevychází pouze z textů Starého a Nového Zákona, ale uznává rovněž analogie v mytologiích jiných náboženství, jako je např́iklad mýtus o znovuvzkříšení duše spojený s postavou Krista, Osirise či Persefony. Je třeba zdůraznit, že alchymie není pouze evropskou záležitostí, nebot' se současně rozvíjela také např́íklad v Číně.

Ve všech oblastech se v alchymii zpravidla rozlišují dva směry: exoterický proud (provádění transmutací kovů) a esoterický (zkoumání adeptova subjektu).

${ }^{1}$ Do polského jazyka přeložili výše jmenované tituly Marcin Babko (Aniot, 2002) a Leszek Engelking (Siostra, 2002; Nocna praca, 2004).

${ }^{2}$ Smrt je jedno z klíčových témat rovněž v Topolově posledním románu Citlivý člověk (2017), kde však neplní symbolickou funkci v rámci hrdinovy mystické iniciace, jako je tomu ve výše uvedených titulech. 
V kontextu alchymie je adeptovo vědomí v komplementárním vztahu se světem, a proto se transformace dotýká obou poloh. K této vzájemné interakci mezi mikrokosmem a makrokosmem se vztahuje Paracelsův pojem dvojí firmament neboli dvojí nebe ${ }^{3}$, který měl v oblasti medicíny vyjadřovat souvztažnost mezi lidským tělem a astronomickým nebem. Tento koncept se dnes opět stává velmi populární především v oblasti umění ${ }^{4}$.

Iniciačnímu románu a jeho mystickým aspektům se soustavně věnuje Daniela Hodrová. Autorka Románu zasvěceni (1993) upozorňuje rovněž na třífázové alchymistické iniciační schéma, jež je v rovině příběhu provázáno se symbolikou trojice heraldických barev: černá (katabáze), bílá (očista, vzkříšsení), červená (zasvěcení). Každá z těchto barev je v kombinaci s iniciačním prostorem, motivem, atributem (černý oděv femme fatale, svatební šat panny, rudá růže a jiné) příznačná pro určitou iniciační fázi: nigredo, albedo, rubedo 5 .

Alchymistická transformace se děje na základě tvořivé redukce (proces přeměny probíhá $\mathrm{v}$ jednom těle), jejíž realizace je podmíněna destruktivními procesy souvisejícími s konfrontací znepřátelených protikladů. Mystická smrt je tedy složitým a dlouhodobým procesem, během něhož starý svět umírá, aby se mohla zrodit jeho dokonalejší forma ${ }^{6}$. Analogii makrokosmu představuje adeptův mikrokosmos (duše, duch, tělo), který je se světem v neustálé interakci. Proces díla takto směřuje $\mathrm{k}$ nové syntéze polarit a navrácení původního těla. Jung v souvislosti s touto tvořivou redukcí vzpomíná axiom Marie Prorokyně kurzívou, jenž je metaforou cesty k celosti: ,Z jednoho se stanou dva, ze dvou tři a $\mathrm{z}$ toho třetího vzejde jedno jako čtvrté‘7. Jedno je zde výchozím bodem, počátečním stavem starého a jednostranného systému, druhé je jeho následnou konfrontací (nigredo), třetí vyjadřuje smíření protikladů, sjednocení vědomí a nevědomí (albedo), čtvrté je novou, dokonalejší formou, hermafroditním tělem (rubedo). Podle Carla Gustava Junga je pak kvaternita stejně jako kruh symbolem dokonalosti v protikladu ke křestanské trojnosti.

${ }^{3}$ Srov. C. G. Jung, Paracelsica, přel. M. Žemla, Praha 2002, s. 20.

${ }^{4}$ V konceptuálním umění pracoval s koncepcí komplementárního vztahu obou firmamentů např́iklad neměcký umělec a vysokoškolský pedagog Joseph Beuys (1921-1986). Ve svých performancích se často konfrontoval s německým nacismem. Jeho nejvýznamnější uměleckou akcí tohoto zaměření byla performance pro Fluxus Festival (Aachen, 1960). Důraz na celospolečenskou transformaci nejlépe vystihuje jeho rozšířený pojem umění, takzvaná sociální plastika, která kromě tradičního chápání plastiky zahrnuje také významy duchovní a společenské (C. Mesch, Critical lives - Joseph Beuys, Glasgow 2017).

${ }^{5}$ Srov. D. Hodrová, Román zasvěcení, Jinočany 1993, s. 214.

${ }^{6} \mathrm{~V}$ alchymistické symbolice vizualizováno například jako smrt krále roztrháním či rozčtvrcením a jeho znovuzrození v ohni nebo rakvi, patrné na grafikách Michaela Maiera (1568-1622) z knihy Atalanta fugiens (1617).

${ }^{7}$ D. Sharp, Slovník základních pojmů psychologie C. G. Junga, přel. V. Stavová, Brno 2005, s. 34 . 
Analogii tohoto axiomu nalezneme přirozeně v mýtu, pohádce, v iniciačním románu a konečně také v postmoderním románu ${ }^{8}$.

Iniciační schéma alchymistického procesu se $\mathrm{v}$ Topolových prózách uplatňuje následovně:

Alchymistický proces

$1=$ Starý a jednostranný systém.

2 = Následná konfrontace, nigredo.

výrazná změna často

opouští domov a stává se

3 = Smíření protikladů, albedo.

4 = Nová, dokonalejší forma (hermafrodit), rubedo.
Př́iběh

Hrdinův život před iniciací.

Počínající chaos v životě hrdiny, spojená se ztrátou rodičů. Hrdina solitérem. Na cestě potkává průvodce ${ }^{9}$.

Dochází k výraznému obratu ve vztahu k osudové ženě.

Okamžik osvícení, narození dítěte (př́íchod mesiáše).

Počáteční operace adeptovy transformace se projevuje jako melancholie. Nigredo (černání) je vyjitím ze stavu surového chaosu cestou hnití a rozkladu, př́ípadně rozčtvrcením starého těla. Nabízí se rovněž srovnání s iniciací šamana. V tomto chaosu je ukryta alchymická prima materia, výchozí substance proměny, jejíž malosvětskou analogií je člověk jako materia sekunda (hlavní subjekt procesu). V první fázi je třeba tento chaos rozdělit na dvě části, aby byl subjekt zbaven své staré formy. Duše se pak postupně osvobozuje od hrubého těla, které je nahrazeno jeho astrální alternativou. Následuje proces čištění a bělení. V této fázi zvané albedo je třeba znepřátelené protiklady opětovně spojit v těle, které je již hermafroditní povahy - je jím samotný Mercurius. K zrození hermafrodita dochází v poslední fázi rubedo (zčervenání, rudnutí). Někdy bývá uváděna i čtvrtá fáze citrinitas (žloutnutí).

\section{Nigredo jako stav vědomí}

Fantasmagorické tempo Topolova románového debutu Sestra umožňuje hrdinovi jménem Potok prožít nigredo hned několikrát. Cílem jeho zběsilého putování je femme fatale Černá alias Sestra odkazující svou přezdívkou k významné figuře

${ }^{8} \mathrm{Z}$ českých autorů jesou to dále např́íklad Michal Ajvaz, Daniela Hodrová nebo Jiřri Kratochvil.

${ }^{9}$ Vedle vybraných próz (Sestra, Anděl, Noční práce) začíná př́iběh nigredickou fází také $\mathrm{v}$ titulech Kloktat dehet (2005) a Chladnou zemí (2009). V prvním z nich se hrdinovi zbortí starý svět $\mathrm{v}$ okamžiku smrti jeho mladšího bratra (rodiče se jich zřekli již dávno), v druhém po ztrátě rodičů (otec umírá po hádce se synem následkem pádu z hradeb terezínské pevnosti, matka si bere život dobrovolně). V Sestře dochází k zániku starých struktur jednak v rovině individuální (přerod v dospělost; v tomto období se z života hrdiny vytrácí jeho první milenka Bílá Psice, která mohla být zavražděna samotným hrdinou), jednak v rovině společenské (porevoluční transformace Československa). V Andělu se hrdinovi hroutí především jeho vnitřní svět, nebot' u něj propuká schizofrenie, zatímco v Noční práci je spouštěčem hrdinovy iniciační cesty náhlé odloučení od rodičů (jeho iniciace začíná pohřbem dědečka). 
alchymistického procesu, kterou je soror mystica čili mystická sestra ${ }^{10}$, patrné např́íklad v románu Johanna Valentina Andreaeho Chymická svatba Christiana Rosenkreutze roku 1459, v originálu Chymische Hochzeit: Christiani Rosencreutz. Anno 1459 (1616).

Během své pouti po zapomenutých koutech východní Evropy je Potok nesčetněkrát konfrontován se smrtí v jejich nejrůznějších podobách (záhadná smrt hrdinovy milenky Bílé Psice, setkání se smrtákem v Osvětimi, zabití dvojníka, překonání vlastní smrti a podobně). Po těchto zkušenostech obvykle následuje neméně intenzivní období odpočinku. Setrvá-li však Potok na jednom místě př́iliš dlouho, podlehne duchovní stagnaci. „Věděl jsem, že musíme vypadnout, každý den mi to bušilo v mozku. [...] A možná, že jsme měli oba trochu strach zas vyrazit na cestu“11. A dále: „Ale zřejmě nastalo období únavy. Deprese, kdy v šeru hledáš už jen mihotavý záblesky jakýhokoli vzruchu, abys měl pocit, že vůbec žiješ“ ${ }^{\text {“12. }}$. Potok je však $\mathrm{k}$ tvořivému pohybu předurčen. Konečně popření stagnace má obsaženo ve svém iniciačním jméně. Místa své stagnace nakonec úspěšně opouští sám bez ohledu na ostatní, jež ponechává vlastnímu osudu. Takto se chová každý mytologický hrdina, nebot' jednou z podmínek úspěšné iniciace je konfrontace s vlastní samotou. Jednotlivé fáze odpočinku odkazují v Sestře ke zbystření smyslů, díky němuž je Potok schopen prohlédnout iluzivnost světa. Spočinutí však nikdy nesmí trvat př́iliš dlouho. Potokova duševní rozpolcenost se projevuje prostřednictvím snů, neblahých tušení a temných vizí.

V závěru nigreda dochází k překonání vlastního stínu, např́íklad na městské skládce (viz dále) nebo mnohem dříve během pobytu na městském trhu poblíž slovensko-mad’arské hranice. „Byly to stíny. Ale tentokrát jsem je viděl. Jen velmi matně, chvílemi vypadali jako havrani, chvílemi to byly obrysy těl, šli prostorem, byli dva [...] tloukli sebou, ale jejich srdce byla malá, brzy jsem poznal, že se každé vejde do dlaně. Umírali a syčeli jak hadi, to už neznali slova“"13. Figura havrana má v alchymii významné postavení, nebot' odkazuje k putrefakci (hnití, rozklad), jež je součástí počáteční fáze. Pro alchymistické vyjádření jsou dále signifikantní motivy čtvrcení těla, ohně, černého slunce, kostí, kostlivců, rakví, všelijakých plazů a podobněr $\breve{l}^{14}$.

Slyšel jsem hlas

viděl jsem stroje

byli tam havrani.

10 Tato postava reprezentuje v Jungově psychologii přenosu polohu vědomí. Spojení mystické sestry s adeptem vede k prolnutí s nevědomou sférou, kterou zastupuje animus s animou (v alchymii král s královnou).

11 J. Topol, Sestra, Praha 1994, s. 373.

12 Ibidem, s. 395.

13 Ibidem, s. 381-382.

14 Nabízí se srovnání s expresivním ztvárněním adeptovy katabáze na některých dobových ilustracích, jako jsou např́íklad iluminace v alchymistickém traktátu Aurora consurgens pocházejícího z pozdního XIV století (první český překlad známý pod názvem Jitřní zářre, 1585) nebo některé výše zmíněné dřevoryty Michaela Maiera. 
Dva černí ptáci s peřím olízaným děvkou syčeli sliny děvky

kapaly na tvrdou zem strhl jsem drát

a zabil je drápy a zobáky a drát

se staly náhrdelníkem.

Svítilo slunce

ale byla zima války. Měl jsem svoje vlastní náboženství.

Lidé byli potravou smrti. Tu jsem držel v rukou

a hladil. A bál jsem se.

V krvi se rodily stvůry.

$\mathrm{V}$ půdě rostly skvrny.

Voda přemílala hlínu a kosti v ní.

Dostal jsem se do města a našel ten dům

byla tam moje láska

měla bílý šaty

smála se

a byla mrtvá ${ }^{15}$.

V Andělu je vznešené téma duchovní transformace bagatelizováno např́íklad záměnou alchymistické laboratoře za fetácká doupata a varny tvrdých drog. Př́ízemnost je akcentována také v postavě hlavního hrdiny, kterým je mladý schizofrenik Jatek. Jeho iniciační jméno poukazuje k umrtvení starého těla rozčtvrcením, jež lze $\mathrm{v}$ kontextu alchymistické iniciace vztahovat $\mathrm{k}$ nigredické fázi. Jatek na počátku př́iběhu prochází velmi těžkým obdobím. Jeho vazby na rodiče jsou téměř nulové stejně tak jako pravděpodobnost udržet si milostný vztah. Jatek nenávidí svět a jeho nenávist jen prohlubuje jeho vnitřní konflikt, což také zhoršuje jeho už tak velmi těžký psychický stav. Rozpolcenost Jatekova vědomí se projevuje psychickým i fyzickým utrpením (viz také předchozí ukázky). „Je to den, kdy má být muž konečně zlomen. Kdy má jít střepy a vrážet si do těla ohnivý trny. Kdy se má pokrýt hnilem a prachem a špínou kosmu, musí být červem, má zpod prahu ústy tahat červy, má cítit bolest, musí se pořezat, musí se zbít. Pokud to za něj zrovna nedělá někdo jinej“16. Charakteristické je tedy i hrdinovo duševní zatemnění, nenávist vůči světu a všudypř́tomná smrt. Srovnejme s následující ukázkou:

nebe se roztrhne

a mezi rudejma plachtama

uvidíš tělo

možná je to něčí hrud'

a je probodlá a ty cítís

nenávist světa $\mathrm{v}$ sobě

a víš:

všichni tady budou mrtvi

a tvoje nenávist a tvoje hrůza

je silná je tak mocná

chce vybuchnout

a chce tě roztrhat:

15 J. Topol, Sestra..., s. 382.

16 J. Topol, Anděl, Praha 2000, s. 33.

Slavica Wratislaviensia 168, 2019

(C) for this edition by CNS 
$\mathrm{v}$ den kdy se to stane

se všechno cos kdy jedl

v tobě znovu uvaří ${ }^{17}$.

Jatek-intelektuál se nehledě na svou schizofrenii pokouší socializovat. Po návratu z psychiatrické léčebny přijímá náročnou práci kotelníka, pro kterou mu již nezbývá čas pro vlastní duchovní rozvoj. „Není už čas vrátit se ke knihám? Ale kam? Jak? Nejsem v pasti? Mám si snad najít jiný zaměstnání a bydlení? Ale jak? Kde?" ${ }^{18}$. Psychická choroba se vrací v podobě duchovní smrti, se kterou se Jatek opakovaně konfrontuje za zdmi psychiatrického ústavu. Tento stav doprovázejí nesnesitelné krvavé vize:

Jatek mrk. Ale nezmizelo to. Viděl ji, krev, něco jako rudou plástev, jako blánu v levém oku. Pak v pravém. Předtím krev tekla z oblohy, padala mu do očí. Měl chut' uhnout tělem, schoulit se okolo toho rudého, přes sítnici náhle se rozpínajícího bodu, nějak ho omotat svalama, šlachama, kostma, vlasama, vším, co nepochybně patřilo jen jemu, a snad chtěl v sobě to vidění rozpustit ${ }^{19}$.

Jatekovy sny nabývají kolektivní povahy. „Budil se s výkřikama, budil ostatní, rušil. Až injekce bodly. A on se konečně mohl nořit do snů. Hrůzných. Převalovaly se v nich barvy a zrůdy a vítězil purpur krvavejch mraků planety Chaos“20. Se zřetelem na název Topolovy novely nás „krvácející nebe“ a „purpur krvavých mraků planety Chaos“ jednoznačně odkazuje k novozákonnímu Janovu Zjevení, v jehož závěru dochází k zrození nové země (připomeňme, že v první fázi dochází k umrtvení starého těla-světa za účelem vzniku nového). Toto téma nacházíme rovněž v Andělu (viz sedm andělů ve Zjevení Jana). Destrukce překračuje hranici hrdinova mikrokosmu. Jeho duchovní smrt se děje současně s apokalypsou.

Apokalypsa potřebuje svého démona i s veškerými jeho lákadly. V Andělu je tím démonem tricksterská postava pražského mafiána Pernici ${ }^{21}$, kterého hrdina v závěru knihy zneškodní ve velkolepém stylu amerických akčních filmů. Klíčové jsou ve Zjevení také postavy svědků-proroků:

A povolám své dva svědky, a oblečeni v smuteční šat budou prorokovat tisíc dvě stě šedesát dní. [...] A kdyby jim chtěl někdo ublížit, vyšlehne oheň z jejich úst a sežehne jejich nepřátele; takto zahyne každý, kdo by jim chtěl ubližit. Ti dva svědkové mají moc uzavřít nebesa, aby nebylo deště za dnů jejich prorokování, a mají moc proměnit vody v krev a sužovat zemi všemi možnými pohromami, kdykoli budou chtít ${ }^{22}$.

${ }^{17}$ Ibidem, s. 56.

18 Ibidem, s. 23.

19 Ibidem, s. 12.

${ }^{20}$ Ibidem, s. 13.

${ }^{21}$ Viz podrobněji T. Foldynová, Demiurgický svět schizoidního adepta Jateka (Hledání vnitřního řádu v Andělu Jáchyma Topola), [in:] Chaos i ład w języku i w literaturze czeskiej / Chaos $i$ soulad v českém jazyce a literatuře, Racibórz-Poznań 2016, s. 51-59.

22 J. Topol, Andél..., s. 11. 
Po vyslovení proroctví se vynoří z propasti šelma, která oba proroky usmrtí. Jejich bezvládná těla zůstanou po tři a půl dne ležet a potom je Bůh opět povolá k životu. V Andělu sehrává topos propasti významnou roli. Prostorem titulní pražské křižovatky pulsuje neviditelná jáma vtahující těla kolemjdoucích hříšníků. Ušetřeni jsou zvířata, někteří staří lidé a matky s dětmi. Jatek s Nad'ou jsou němými svědky hrůzného mizení lidí, nebot' pouze oni dva jsou schopni jámu vidět. Nad’a je téměř dospělá, a přesto uvězněná $v$ těle dítěte (s motivem věčného dítěte se setkáváme také $\mathrm{v}$ Citlivém člověku, kde jedno z Mourových dvojčat klame svým batolecím tělem, ačkoliv jeho bratr již prochází pubertou). Snad její dětská podoba souvisí s její citlivostí. Její jméno odkazuje k naději (srovnej s dalšími ženskými postavami Ljubou a Věrou). V závěru př́iběhu však právě ona padne za obět' rituální vraždy. Její mučednická smrt má být vykoupením za hříchy celého lidstva. Zemřít má i Jatek, ale nikdo mu nakonec neublíží, nebot' členové sekty včetně jejich duchovní vůdkyně se zlikvidují sami mezi sebou.

Hrdinova smrt má v př́iběhu čistě symbolickou povahu, jeho znovuzrození se děje na úrovni vědomí. Konečně optimistický konec autor slibuje již v úvodním citátu z Knihy žalmů (srov. Žalm 124,7), jehož posláním je víra v Hospodina, který nad lidmi drží ochrannou ruku. Nesmíme však brát př́iliš vážně hrdinovu duševní chorobu, Jatek totiž není duševně vyšinutým bláznem stylizujícím se do role svědka a proroka apokalypsy (na to jsou zde jiní experti). Spíše než bláznem je Jatek zbytečným člověkem, jehož outsiderství spočívá v př́lišné citlivosti, pro kterou ve světě není dostatek místa. Nezapomínejme, že určitá míra bláznovství je jedním z hlavních atributů hrdiny. Bláznovství ve smyslu schopnosti vnímat svět jinak než běžný smrtelník a připouštět jeho ambivalentní povahu, vidět jeho temnější kontury. A takto ho náš hrdina i vidí: v krvi, hnisu a špíně, zkažený a nepřátelský. Ovšem ani úspěšná transformace světa zde nevyznívá zcela jednoznačně, město totiž zůstává stále stejně nečisté. Ani to nebe se v závěru nezmění, je pořád stejně rudé. Snad jen ta jáma na čas zmizela. A přece je ta „nová doba“ něčím lepší. Obsahuje naději, která spočívá v hrdinově novém pohledu na okolní svět.

\section{Nigredický prostor}

Výrazným rysem iniciačního modu je pojetí místa jako stavu hrdinova vědomí. Hrdina Anděla projikuje veškerou svou vnitřní temnotu do prostoru, který jej obklopuje. Analogií jeho zmatené a zatím nezasvěcené mysli je velkoměsto, zmenšený model nepřátelského světa. Jatek pracuje v podzemí temné kotelny připomínající peklo. V nelidském horku, vichru a jedovatých výparech tady pracuje „opravdová sběř“, která podle tradice vždy na počest nově př́íchozího vhazuje do kotle živé kočky. Z podzemí kotelny směřjí Jatekovy kroky do hlučného domu s pavlačí, kde si pronajímá jednu místnost rozděleného bytu. $V$ tomto pokoji Jatek čelí násilí v domě, který je stejně nepřátelský jako celý okolní svět. V potemnělých chodbách domu se člověk nedočká ničeho dobrého. „Jednou si na schodišti 
všimnul cákanců krve. Chtěl se vyhnout, ale zjistil, že se otřel o stěnu. Tam byla krev taky. Jednou otevřel dveře, vyběhl z nich chlápek s nožem v ruce [...] Někdy ho v noci probudily výkřiky, sousedi se rvali, nebo slavili, nebo oboji‘‘23.

Počáteční temná fáze je prostorově vyjádřena rovněž v úvodu románu Noční práce, jejíž hrdina, mladý Ondra, podstupuje svou iniciaci v době, kdy v jeho zemi vrcholí politická krize, jejíž intenzita halí krajinu do zimního hávu ${ }^{24}$. Konflikt v úrovni hrdinova mikrokosmu tedy opět probíhá paralelně se společenským konfliktem. Stav země i hrdinova vědomí se odráží v krajině:

Kry rozbíjely břehy, voda pod ledovou krustou v meandrech a slepých ramenech tepala krajinou, $\mathrm{v}$ zimě byla řeka $\mathrm{v}$ bílé krajině jediným pohybem, kry se převalovaly jedna přes druhou, lámaly se, trčely $\mathrm{z}$ nich větve a kmeny stromů. [...] V matném ledu zamrzly větvičky, vítr je zkroutil, serval ze stromů, zmrzla tam i malá vodní krysa se špičatým čumákem plným zmrzlé krve $[\ldots]^{25}$.

Po zimním obraze s pulsující řekou pod vrstvami ledu následuje zobrazení téže krajiny v letním období:

Leží v lod'ce, vedro ho uspává, slyší vítr, vodu všude okolo, slyší hmyz. Plul jen chvíli, zastavila ho změt' naplaveného dříví, kořeny vyrvaných stromů trčely do vzduchu. Kůra ze stromů visela $\mathrm{v}$ cárech, na kmenech zůstaly po krách jizvy jak po seknutí, větve stromů šátraly v hlubině, v jámách vody zelenavých mechem a hnijící trávou praskaly bubliny ${ }^{26}$.

Smrt je obsažena také v letní variantě. Oba fragmenty vypovídají mnohé o souvztažnosti pohybu a statiky $v$ přírodě, přičemž pohyb je uskutečňován především vodním živlem. V zimní variaci je tok řeky ukryté pod ledovými krustami jen tušený, zatímco v létě je její pohyb akcentován protilehlým procesem tlení (trávy, dřeva). Povšimněme si zde dvojí povahy vodního živlu: tekutost x tuhost. Zimní řeka konzervuje uhynulé, letní rozkládá.

Jedním z nejpozoruhodnějších Topolových toposů smrti je městská skládka v románu Sestra. Skládka jakožto symbol rozkladu hmoty i ducha je místem Potokova setkání s jeho vlastním stínem. Ten se mu nejprve zjeví v podobě nejčistší nevinnosti, v těle malého kluka. Skládka je demytizovanou svatou horou, axis mundi. Je dalším z míst stagnace a tlení ${ }^{27}$, která se $\mathrm{v}$ Topolově tvorbě tak hojně vyskytují. V alchymistickém kontextu je pak místem nigredické smrti, kde je třeba zabít v sobě to staré, aby dalo průchod novému. Hrdina svůj stín poráží zastřelí jej stř́ibrnou kulkou, kterou si odlil z talismanu čenstochovské madony ${ }^{28}$.

${ }^{23}$ Ibidem, s. 22-23.

24 Srov. s proměnou počasí v Egona Bondyho Sklepní práci $(1988,1997)$.

25 J. Topol, Noční práce, Praha 2001, s. 9.

26 Ibidem.

27 Srov. s kapitolou Měl jsem sen (Sestra), kde se děj odehrává v Osvětimi na haldách lidských koster.

${ }^{28}$ „Zvedl jsem pušku a přiložil mu hlaveň na spánek, zat’al jsem zuby a stiskl spoušt’... prásklo to... překotil se naznak, z hlavy mu crčela krev, kulka mu rozbila obličej... tělo se zkroutilo, oči chvíli mžikaly a pak je zavřel a byl pryč. Udělal jsi to, ozval se sykot. Seš volnej“ — J. Topol, Sestra..., s. 433. 
Tato část iniciace bezpochyby sdílí celou řadu společných rysů s Bondyho šamanem ze stejnojmenného románu (Šaman, 1976). Titulní hrdina se svým alter egem setká na ledovci. $Z$ počátku se mu zlý šaman jeví jako stín, později ukáže svou d'ábelskou podobu a následně způsobí jejich záměnu. V románu Egona Bondyho je iniciace hrdiny završena pomocí šamanského bubínku ${ }^{29}$, v Sestře je magickým předmětem stř́ibrný medailon přetavený na kulku. Po konfrontaci se stínem se zborcený svět hrdiny znovu formuje a dostává nový smysl. I zde tedy dochází k zániku starého světa prostřednictvím mystické smrti, jež je nutnou podmínkou pro vznik světa nového.

\section{Závěr}

Motivická analýza Topolových prozaických děl Sestra, Anděl a Noční práce ukazuje na velký výskyt motivů smrti a zmrtvýchvstání, které jsou neodmyslitelnou součástí Topolovy poetiky. Tyto motivy se přirozeně podílejí na utváření iniciačních př́iběhů, pro jejichž architekturu je $\mathrm{v}$ př́ípadě tvorby tohoto autora fundamentální aktualizace archetypů a mytologických struktur. V př́ípadě výše zmíněných próz jsou tyto struktury ztvárňovány prostřednictvím symbolů alchymistického procesu, jenž sdílí řadu společných znaků s tradičními iniciačními schématy a jenž s sebou přináší nové kvality spočívající v transgresi mezi individuální a kolektivní polohou světa.

Vysoký styl alchymistické iniciace je zde ovšem do značné míry bagatelizován zapojením groteskních či parodických prvků. Autorova strategie snižování vznešeného však nemá charakter znehodnocující, nýbrž obrozující, nebot' ideovou koncepci alchymie zachovává. Vezmeme-li v potaz těsný vztah mezi klasickým schématem iniciačního př́íběhu a alchymií jakožto uměním duchovní transformace, získáme další interpretační klíč k motivům, které pulsují Topolovými romány jako alchymistické Opus Magnum.

\section{Bibliografie}

Bible. Písmo svaté Starého a Nového zákona, ekumenický překlad, Ekumenická rada církví, Praha 1984.

Bondy E., Šaman, Praha 2006.

Eliade E., Culianu P. I., Slovník náboženství, přel. M. Lyčka, Praha 2001.

Foldynová T., Demiurgický svět schizoidního adepta Jateka (Hledání vnitřního řádu v Andělu Jáchyma Topola), [in:] Chaos i ład w języku i w literaturze czeskiej / Chaos i soulad v českém jazyce a literature, Racibórz-Poznań 2016.

Helmond J., Alchymie jako cesta zasvěceni, přel. P. Krummer, Praha 2007.

29 „Se zoufalým úsilím zvedl jeden svůj pařát — nahmatal bubínek u boku — a prudce zabubnoval rytmus Velkého transu. Zatočila se mu hlava, nekonečný ledovec letěl na něj shůry, obrys d'áblovy postavy se rozplizl a zahřměl jenom rachot jeho prdu a šaman pocítil tak nesnesitelnou bolest, o jaké nevěřil, že vůbec může být. To bylo to poslední. Šaman definitivně klesl“" — E. Bondy, Šaman, Praha 2006, s. 123. 
Hodrová D., Citlivé město. Eseje z mytopoetiky, Praha 2006.

Hodrová D., Román zasvěcení, Jinočany 1993.

Jung C. G., Paracelsica, přel. M. Žemla, Praha 2002.

Mesch C., Critical lives - Joseph Beuys, Glasgow 2017.

Roob A., Alchemie \& Mystic, Köln 2005.

Sharp D., Slovník základnich pojmů psychologie C. G. Junga, přel. V. Stavová, Brno 2005.

Topol J., Andèl, Praha 2000.

Topol J., Noční práce, Praha 2001.

Topol J., Sestra, Praha 1994.

\section{Mystical death in selected prose by Jáchym Topol}

\section{Summary}

The distinctive feature of most of the prose works by Jáchym Topol is the theme of mystical initiation with overlaps to alchemy, which is characterized by significant motives of death and resurrection. This aspect is most evident in the books Sestra, Anděl and Noční práce, where social transformations take place concurrently with the spiritual rebirth of the hero. The first part of this article presents a three-phase initiation scheme applied in alchemy. The second part of the text is devoted to a motivational analysis, taking into account the nigredo phase, which is characterized by the very frequent occurrence of death motives.

Keywords: Jáchym Topol, Sestra, Anděl, Noční práce, alchemy, nigredo

\section{Mistyczna śmierć w wybranych utworach Jáchyma Topola}

\section{Streszczenie}

Charakterystyczną cechą twórczości Jáchyma Topola jest temat mistycznej inicjacji i jego aspekt alchemiczny oraz szamanistyczny, które są bardzo ściśle związane z motywami śmierci i zmartwychwstania. Motyw śmierci odgrywa kluczową rolę przede wszystkim w powieściach Sestra, Anděl oraz Noční práce, w których transformacja społeczna odbywa się równocześnie $\mathrm{z}$ odrodzeniem duchowym bohatera.

W pierwszej części artykułu przedstawione zostały trzy podstawowe fazy inicjacyjne stosowane $\mathrm{w}$ alchemii. Treścią drugiej części tekstu jest analiza wymienionych prac, $\mathrm{z}$ bardzo wyraźnie wyeksponowaną pierwszą fazą nigredo, połączoną z przeżywaniem śmierci oraz z obrazami umierania na poziomie symbolicznym.

Stowa kluczowe: Jáchym Topol, Sestra, Anděl, Nočni práce, inicjacja mistyczna, alchemia, nigredo 